\title{
PENGEMBANGAN MULTIMEDIA PEMBELAJARAN INTERAKTIF DENGAN MENGGUNAKAN SOFTWARE ADOBE FLASH CS6 PROFESSIONAL PADA SISWA SMP KELAS VIII
}

\author{
Febrita Melati Setiawan ${ }^{1)}$ Asni Johari ${ }^{2)}$ Muswita $^{3)}$ \\ Program Studi Pendidikan Biologi FKIP Universitas Jambi \\ e-mail: febrita_melati@yahoo.co.id
}

\begin{abstract}
The humans' respiratory system is one of the material subject biology in eight grades of junior high school. Human respiratory system material requires an understanding of the concept. The use of interactive multimedia is one way to presenting the material. Based on the observation in SMP 24 Jambi found that the students are difficult to understand the material because the teacher is not optimal in using the media. Therefore, the teachers need a learning media to describe the material. Interactive multimedia flash can be used as the media. The purpose of this research is to develop and to know the students responses in the multimedia interactive learning material on the human respiratory system for junior high school in VIII class using Adobe Flash Professional Cs6. This research is the development research. The research design in this study follows the ADDIE development model.ADDIE development model has five stages: analysis, design, development, implementation and evaluation. Before the multimedia product tested it will be validate by the expert to determine the feasibility of the product, the team experts are material expert and media expert. The result of the validation from material expert obtained $87.1 \%$ score with very good categories and the result of the validation from media expert obtained $80 \%$ score with good categories. The students' response to the media for small group is in very good category with of $87.8 \%$ and for large group is classified in very well category with $87.1 \%$. Based on the result, the conclusion this study is the multimedia interactive learning on the material of the human respiratory system got a very good response from the students. Multimedia interactive learning on the material in the human respiratory system can help the teacher in the learning process and can be used as self-learning that students can use at school and outside school hours.
\end{abstract}

Keywords: Interactive multimedia, Adobe Flash Professional CS6, Human Respiratory System

\section{PENDAHULUAN}

Dalam dunia pendidikan, khususnya pendidikan Biologi untuk tingkat SMP sudah banyak menggunakan teknologi dalam pembelajarannya serta menuntut siswa untuk aktif dalam proses pembelajaran, keberadaan guru adalah sebagai fasilitator yang diharapkan mampu membuat kondisi pembelajaran yang menarik serta dapat meningkatkan minat belajar siswa. Minat siswa untuk belajar merupakan kekuatan yang bersumber dari diri siswa. Minat belajar siswa merupakan salah satu bagian dari motivasi belajar.
Minat belajar siswa akan dapat tumbuh dan terpelihara apabila proses mengajar guru dilaksanakan secara bervariasi, antara lain dengan bantuan media pembelajaran.

Media pembelajaran merupakan suatu teknologi pembawa pesan yang dapat digunakan untuk keperluan pembelajaran, media pembelajaran merupakan sarana fisik untuk menyampaikan materi pelajaran. Media pembelajaran merupakan sarana komunikasi dalam bentuk cetak maupun pandang dengar termasuk teknologi perangkat keras (Rusman, 2013:160). Menurut Kustandi dan Sutjipto (2013:8), 
media adalah alat yang dapat membantu proses belajar mengajar dan berfungsi untuk memperjelas makna pesan yang disampaikan, sehingga dapat mencapai tujuan pembelajaran dengan lebih baik dan sempurna. Dalam hal ini media pembelajaran dapat membantu membangkitkan motivasi belajar siswa dan dapat meningkatkan prestasi belajar siswa.

Prestasi belajar siswa di sekolah sering diindikasikan dengan permasalahan belajar siswa tersebut dalam memahami materi. Indikasi ini dimungkinkan karena adanya faktor belajar siswa yang kurang efektif, bahkan siswa sendiri tidak merasa termotivasi di dalam mengikuti pembelajaran di kelas. Sehingga menyebabkan siswa kurang memahami materi yang disampaikan oleh guru.

Berdasarkan hal tersebut multimedia interaktif dalam kelas dikembangkan atas dasar asumsi bahwa proses komunikasi di dalam pembelajaran akan lebih bermakna (menarik minat siswa dan memberikan kemudahan untuk memahami materi karena penyajiannya yang interaktif), jika memanfaatkan berbagai media sebagai sarana penunjang kegiatan pembelajaran. Multimedia interaktif dapat diartikan sebagai alat bantu penyampai pesan yang menggabungkan dua unsur atau lebih media, yang terdiri dari teks, gambar, grafis, foto, suara, video, dan animasi yang disajikan secara interaktif dalam media pembelajaran (Kustandi dan Sutjipto, 2013). Penggunaan media dalam suatu proses pembelajaran secara tepat guna dapat meningkatkan mutu pembelajaran. Oleh karena itu dalam proses pembelajaran membutuhkan media yang menarik dan tepat.

Salah satu materi pelajaran biologi SMP kelas VIII adalah sistem pernapasan pada manusia. Sistem Pernapasan pada manusia merupakan materi yang membutuhkan pemahaman konsep. Berdasarkan observasi yang telah dilakukan

di SMP N 24 Kota Jambi, guru belum menggunakan media pembelajaran yang optimal, sehingga materi tersebut sulit dipahami oleh siswa. Oleh karena itu dibutuhkan media pembelajaran yang dapat menggambarkan materi tersebut. Salah satu media yang dapat digunakan yaitu multimedia dalam bentuk Flash. Flash merupakan software yang memiliki kemampuan menggambar sekaligus menganimasikannya, serta mudah dipelajari (Suhendi, 2009:8).

Berdasarkan penjelasan dan permasalahan di atas, maka penulis bermaksud merancang dan membuat media pembelajaran dalam bentuk Flash pada materi Sistem Pernapasan Manusia. Adapun judul penelitian ini adalah

"Pengembangan

Pembelajaran menggunakan Software Adobe Flash CS6 Professional pada Materi Sistem Pernapasan pada Manusia untuk Siswa SMP Kelas VIII"6

\section{METODE PENELITIAN Model Pengembangan}

Penelitian ini merupakan jenis penelitian pengembangan. Penelitian pengembangan adalah metode penelitian yang digunakan untuk menghasilkan produk tertentu dan menguji keefektifan produk tersebut (Sugiyono, 2013:407). Dikatakan demikian karena penelitian ini akan menghasilkan sebuah rancangan baru aplikasi suatu bahasa pemrograman dalam pembuatan media pembelajaran biologi kemudian akan di uji keefektifannya.

Desain dalam penelitian ini menggunakan model pengembangan ADDIE yang dikembangkan oleh Branch (2009). Model pengembangan ADDIE memiliki 5 tahap yaitu analisis (analysis), desain (design), pengembangan (development), implementasi (implementation), evaluasi (evaluation). Adapun langkah-langkah pengembangan 
model ADDIE dapat dilihat pada Gambar di bawah ini.

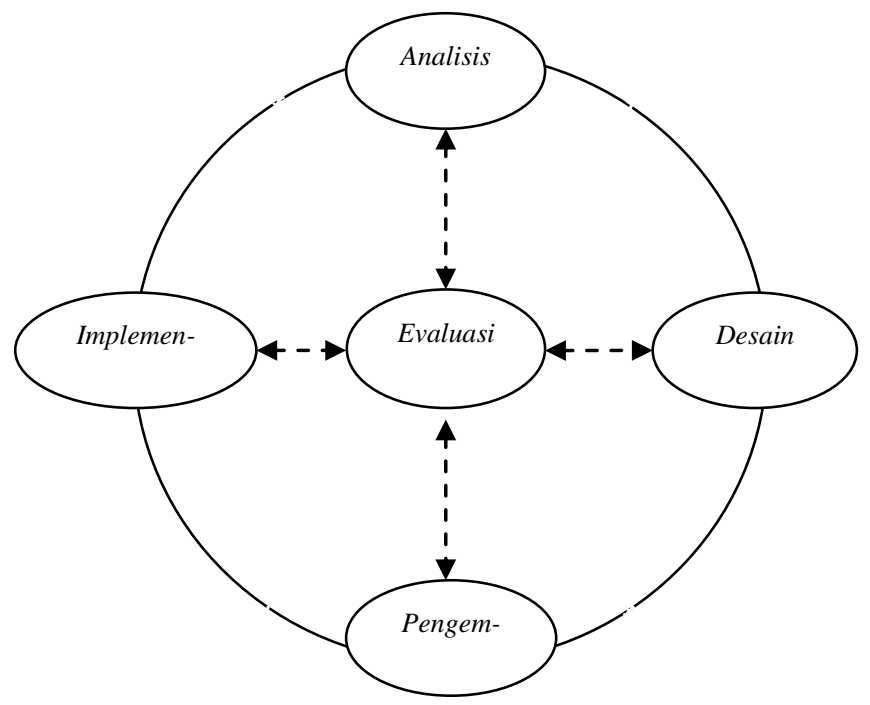

Gambar. Proses pengembangan model ADDIE (Branch, 2009:2).

\section{Prosedur Pengembangan}

\section{Tahap Analisis (Analysis)}

Tahap analisis yaitu menganalisis apa yang dipelajari oleh peserta didik, yaitu melakukan analisis kebutuhan atau mengidentifikasi masalah (kebutuhan) dan analisis materi.

Data didapat dengan menganalisis apa saja yang dibutuhkan siswa dalam proses pembelajaran serta apa saja yang dapat membantu siswa dalam pembelajaran sistem pernapasan pada manusia. Hasil analisis kebutuhan yang dilakukan adalah belum ada media pembelajaran multimedia flash pada materi sistem pernapasan pada manusia. Selain itu siswa membutuhkan suasana belajar baru dengan media pembelajaran yang lebih menarik untuk memudahkan mereka dalam memahami materi sistem pernapasan pada manusia.

Dengan adanya multimedia pembelajaran interaktif dengan menggunakan Software Adobe Flash CS6 Professional yang dikembangkan penulis, diharapkan dapat membantu guru dalam memberikan penjelasan dalam proses pembelajaran serta dapat membantu siswa untuk lebih mudah memahami materi sistem pernapasan pada manusia.

Desain (Design)

Tahap desain pada pengembangan media pembelajaran ini meliputi beberapa tahap yaitu : jadwal, tim, spesifikasi media, struktur materi dan flowchart.

\section{Tahap Pengembangan (Development)}

Pada tahap pengembangan produk, prosedur yang dilakukan adalah pembuatan produk awal dengan terlebih dahulu mempersiapkan bahan, penetapan kompetensi dasar, uraian materi, evaluasi, menetapkan animasi-animasi yang sesuai dengan materi, dan menetapkan narasi atau musik yang sesuai dengan materi yang akan digunakan untuk mengisi suara pada materi yang akan ditampilkan. Tahap ini merupakan tahap pembuatan produk pembelajaran dalam bentuk multimedia interaktif Flash. Setelah produk awal selesai maka langkah selanjutnya adalah validasi dari tim ahli dan kemudian baru tahap ujicoba.

\section{Tahap Implementasi (Implementation)}

Implementasi merupakan proses ujicoba produk. Ujicoba produk yaitu media baru yang sudah valid kemudian diujicobakan kepada siswa. Ujicoba produk multimedia pembelajaran interaktif yang dilakukan pada penelitian ini yaitu pada kelompok kecil dan kelompok besar. Ujicoba produk dilakukan untuk melihat kelayakan media sebagai bahan pembelajaran untuk siswa. Ujicoba dilakukan juga untuk melihat respons siswa mengenai media tersebut melalui pengisian angket.

\section{Tahap Evaluasi (Evaluation)}

Evaluasi merupakan proses perbaikan media pembelajaran. Evaluasi memiliki tujuan untuk melihat kelayakan media (layak atau tidak untuk digunakan 
dalam proses pembelajaran). Evaluasi dilakukan dengan merevisi produk berdasarkan saran-saran ahli media dan ahli materi melalui sebuah angket.

\section{Subjek Ujicoba}

Setelah produk didesain dan dikembangkan serta divalidasi oleh tim ahli, selanjutnya produk diujicoba kepada siswa. Subjek ditetapkan sebanyak 6 orang siswa SMP N 24 Kota Jambi kelas VIII untuk ujicoba kelompok kecil dan 30 orang siswa SMP N 24 Kota Jambi kelas VIII untuk ujicoba kelompok besar, karena menurut Setyosari (2012:226) ujicoba kelompok kecil melibatkan subjek yang terdiri atas 6-8 subjek dan ujicoba kelompok besar melibatkan subjek yang terdiri dari 15-30 subjek.

Pengambilan subjek penelitian ini dengan menggunakan teknik sampling purposive karena menurut Sugiyono (2013:300) sampling purposive adalah teknik pengambilan subjek sumber data dengan pertimbangan tertentu. Tujuannya adalah untuk melihat kemenarikan dan kepraktisan media yang telah dikembangkan.

\section{Jenis Data}

Dalam penelitian pengembangan ini, jenis data yang digunakan adalah data kuantitatif dan data kualitatif. Data kuantitatif diperoleh dari hasil validasi tim validasi yaitu validasi media dan validasi materi mengenai kelayakan dan kemenarikan produk yang telah dikembangkan, serta data yang diperoleh dari siswa setelah dilakukan proses ujicoba produk. Sedangkan data kualitatif diperoleh dari tim validasi media dan materi mengenai saran dan perbaikan produk yang telah dikembangkan, serta saran-saran yang diperoleh dari siswa setelah dilakukan proses ujicoba

\section{Instrumen Pengumpulan Data}

Instrumen yang digunakan untuk mengumpulkan data pada penelitian pengembangan ini berupa :

1. Angket

Menurut Sudaryono $d k k$, (2013:30) angket merupakan suatu teknik atau cara pengumpulan data secara tidak langsung ( peneliti tidak langsung bertanya-tanya dengan responden). Instrumen atau alat pengumpulan datanya juga disebut angket berisi sejumlah pertanyaan yang harus dijawab atau direspon oleh responden.

Angket ini digunakan untuk memperoleh data kualitatif berupa saran perbaikan media dan data kuantitatif tentang kelayakan media. Saran perbaikan media diperoleh dari tim ahli (tahap validasi) yaitu ahli media dan ahli materi, serta saran-saran yang diperoleh dari siswa setelah dilakukan proses ujicoba. Data kelayakan media diperoleh dari hasil validasi tim validasi yaitu validasi media dan validasi materi mengenai kelayakan dan kemenarikan produk yang telah dikembangkan, serta data yang diperoleh dari siswa setelah dilakukan proses ujicoba produk. Angket yang disebarkan berupa angket terbuka dan tertutup.

\section{Observasi}

Observasi yaitu melakukan pengamatan secara langsung ke objek penelitian untuk melihat dari dekat kegiatan yang dilakukan (Riduwan, 2010:57). Observasi digunakan untuk memperoleh data hasil pengamatan ketika dilakukan ujicoba kelompok kecil dan kelompok besar, untuk mengetahui kemudahan siswa menggunakan multimedia pembelajaran tersebut.

\section{Teknik Analisis Data}

Data yang didapat dari pengisian angket tim ahli dan respon selanjutnya dianalisis secara deskriptif yaitu uraian yang 
berupa penggambaran untuk menjelaskan jawaban-jawaban yang diberikan responden dalam angket dengan menggunakan skala Likert. Menurut Mulyatiningsih (2012 :29) bahwa skala likert digunakan untuk kuesioner yang mengungkapkan sikap dan pendapat seseorang terhadap suatu fenomena. Menurut Djaali dan Muljono (2008:28) skala Likert adalah skala yang digunakan untuk mengukur sikap, pendapat dan persepsi siswa baik secara individual maupun kelompok.

Menurut Riduwan (2010:39), Angket yang diolah menggunakan skala likert memiliki instrumen jawaban berupa data kuantitatif dengan interval jawaban sebagai berikut :

$\begin{array}{ll}\text { Sangat baik } & =5 \\ \text { Baik } & =4 \\ \text { Sedang } & =3 \\ \text { Tidak baik } & =2 \\ \text { Sangat tidak baik } & =1\end{array}$

Teknik analisis menggunakan rumus rata-rata untuk menghitung persentase tanggapan adalah :

$$
\%=\frac{\mathrm{F}}{\mathrm{N}} \times 100 \%
$$

Keterangan : $\%=$ Persentase sub variabel

$\mathrm{F}=\underset{\text { variabel }}{\underset{\mathrm{J}}{\mathrm{J}} \mathrm{m} l a h}$ nilai tiap sub

$\mathrm{N}=$ Jumlah skor maksimun

\section{HASIL PENELITIAN DAN PEMBAHASAN}

Berdasarkan pengembangan multimedia pembelajaran interaktif dengan menggunakan Software Adobe Flash CS6 Professional yang telah melalui proses validasi, ujicoba kelompok kecil, dan ujicoba kelompok besar, maka diperoleh hasil sebagai berikut: (1) Desain multimedia pembelajaran interaktif dengan menggunakan Software Adobe Flash CS6
Professional pada materi sistem pernapasan pada manusia yang dapat digunakan dalam pembelajaran di SMP kelas VIII, (2) Penilaian ahli media dan ahli materi terhadap desain dan isi materi multimedia pembelajaran interaktif dengan menggunakan Software Adobe Flash CS6 Professional yang dikembangkan, dan (3) Hasil ujicoba kelompok kecil dan kelompok besar kelas VIII di SMP Negeri 24 Kota Jambi.

\section{Hasil Validasi Ahli Materi}

Multimedia pembelajaran interaktif dengan menggunakan Software Adobe Flash CS6 Professional pada materi sistem pernapasan pada manusia untuk siswa SMP kelas VIII yang telah selesai dikembangkan, kemudian divalidasi oleh tim ahli materi pembelajaran yaitu Dr. Afreni Hamidah, S.Pt.,M.Si. Validasi oleh ahli materi dilakukan sebanyak tiga kali. Hasil validasi pertama dari ahli materi yaitu mendapat skor $47,7 \%$ tergolong kategori "tidak baik", hasil validasi kedua dari ahli materi mendapat skor $80 \%$ tergolong kategori "baik", hasil validasi ketiga dari ahli materi mendapat skor $87,1 \%$ tergolong kategori "Sangat baik". Untuk melihat persentase hasil validasi dari ahli materi dapat dilihat pada Gambar sebagai berikut:

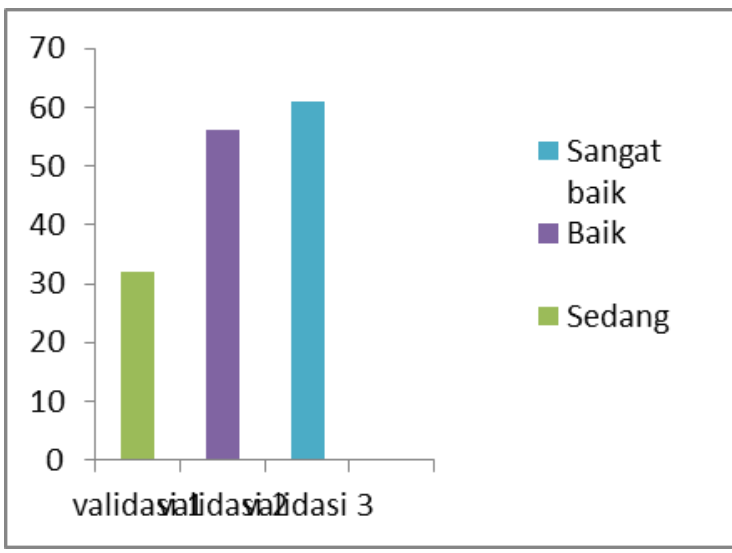

Gambar . Persentase hasil validasi dari ahli materi 


\section{Hasil Validasi Ahli Media}

Multimedia pembelajaran interaktif dengan menggunakan Software Adobe Flash CS6 Professional pada materi sistem pernapasan pada manusia untuk siswa SMP kelas VIII yang telah selesai divalidasi oleh tim ahli materi dilanjutkan validasi oleh tim ahli media pembelajaran yaitu Mia Aina, S.Pd., M,Pd. Validasi oleh ahli media dilakukan sebanyak tiga kali. Hasil validasi pertama dari ahli media yaitu mendapat skor $58,3 \%$ tergolong kategori "sedang", hasil validasi kedua dari ahli media mendapat skor $75 \%$ tergolong kategori "baik", hasil validasi ketiga dari ahli media mendapat skor $80 \%$ tergolong kategori "baik". Untuk melihat persentase hasil validasi dari ahli media dapat dilihat pada Gambar sebagai berikut:

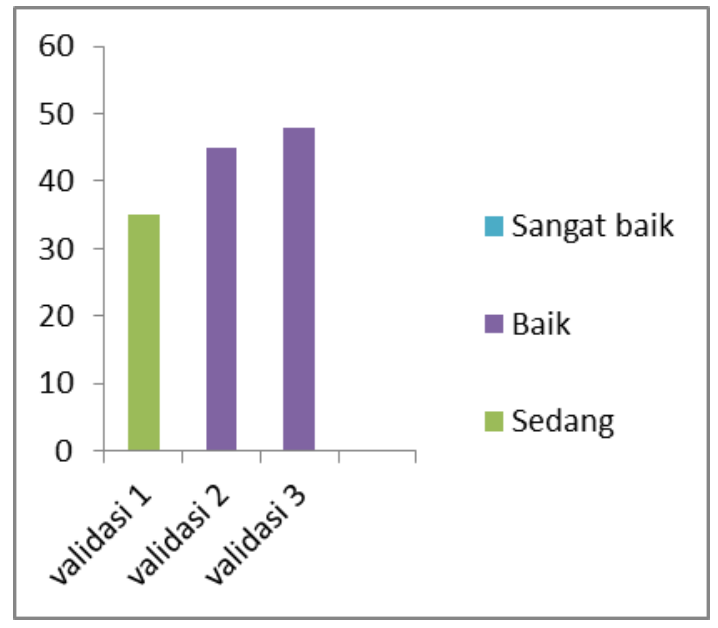

Gambar. Persentase hasil validasi dari ahli media

\section{Hasil Ujicoba Produk}

Produk berupa multimedia
pembelajaran interaktif $\begin{array}{r}\text { dengan } \\ \text { menggunakan Software Adobe }\end{array}$ Flash CS6
Professional pada materi sistem pernapasan
pada manusia untuk siswa SMP kelas VIII
yang telah dilakukan validasi oleh ahli
materi dan ahli media kemudian dilanjutkan
dengan tahap ujicoba kelompok kecil dan kelompok besar. Subjek yang digunakan untuk kelompok kecil adalah 6 orang siswa SMP N 24 Kota Jambi dan untuk kelompok besar adalah 30 orang siswa SMP N 24 Kota Jambi untuk mengisi angket penilaian produk yang dihasilkan. Hasil ujicoba produk untuk ujicoba kelompok kecil dapat dilihat pada Tabel sebagai berikut:

Tabel. Hasil ujicoba kelompok kecil

\begin{tabular}{|c|c|c|c|}
\hline $\begin{array}{c}\text { No } \\
\text { Soal }\end{array}$ & $\begin{array}{c}\text { Aspek } \\
\text { Penilaian }\end{array}$ & $\begin{array}{c}\text { Jumla } \\
\text { h Skor }\end{array}$ & $\begin{array}{c}\text { Persentase } \\
(\%)\end{array}$ \\
\hline 1 & $\begin{array}{l}\text { Pemakaian } \\
\text { warna yang } \\
\text { digunakan } \\
\text { menarik }\end{array}$ & 26 & 86,6 \\
\hline 2 & $\begin{array}{l}\text { Pemakaian } \\
\text { warna yang } \\
\text { digunakan } \\
\text { tidak } \\
\text { mengacaukan } \\
\text { tampilan } \\
\end{array}$ & 25 & 83,3 \\
\hline 3 & $\begin{array}{l}\text { Ukuran huruf } \\
\text { sudah sesuai } \\
\text { dan mudah } \\
\text { dibaca }\end{array}$ & 27 & 90 \\
\hline 4 & $\begin{array}{l}\text { Warna huruf } \\
\text { sudah sesuai } \\
\text { dan mudah } \\
\text { dibaca }\end{array}$ & 27 & 90 \\
\hline 5 & $\begin{array}{l}\text { Suara narator } \\
\text { terdengar } \\
\text { jelas }\end{array}$ & 25 & 83,3 \\
\hline 6 & $\begin{array}{l}\text { Tombol/icon } \\
\text { yang ada } \\
\text { terlihat jelas }\end{array}$ & 25 & 83,3 \\
\hline 7 & $\begin{array}{l}\text { Animasi/simu } \\
\text { lasi yang } \\
\text { digunakan } \\
\text { menarik }\end{array}$ & 25 & 83,3 \\
\hline 8 & $\begin{array}{l}\text { Gambar pada } \\
\text { multimedia } \\
\text { sesuai dengan } \\
\text { materi }\end{array}$ & 26 & 86,8 \\
\hline 9 & $\begin{array}{l}\text { Multimedia } \\
\text { memiliki } \\
\text { ketajaman } \\
\text { gambar yang } \\
\text { jelas }\end{array}$ & 25 & 83,3 \\
\hline 10 & $\begin{array}{l}\text { Multimedia } \\
\text { dapat dimulai } \\
\text { dengan } \\
\text { mudah }\end{array}$ & 27 & 90 \\
\hline
\end{tabular}




\begin{tabular}{|c|l|c|c|}
\hline 11 & $\begin{array}{l}\text { Multimedia } \\
\text { dapat berjalan } \\
\text { dengan baik }\end{array}$ & 28 & 93,3 \\
\hline 12 & $\begin{array}{l}\text { Pengguna } \\
\text { dapat } \\
\text { mengoperasik } \\
\text { an } \\
\text { multimedia } \\
\text { secara } \\
\text { mandiri }\end{array}$ & 27 & 90 \\
\hline 13 & $\begin{array}{l}\text { Materi yang } \\
\text { ditampilkan } \\
\text { pada } \\
\text { multimedia } \\
\text { jelas }\end{array}$ & 29 & 96,6 \\
\hline 14 & $\begin{array}{l}\text { Soal latihan } \\
\text { cocok dengan } \\
\text { isi materi }\end{array}$ & 27 & 90 \\
\hline \multicolumn{2}{|l|}{ Jumlah } & 369 & 87,8 \\
\hline
\end{tabular}

Hasil ujicoba produk untuk ujicoba kelompok besar dapat dilihat pada Tabel sebagai berikut:

Tabel. Hasil ujicoba kelompok besar

\begin{tabular}{|c|c|c|c|}
\hline $\begin{array}{l}\text { No } \\
\text { Soal }\end{array}$ & Aspek Penilaian & $\begin{array}{l}\text { Jumlah } \\
\text { Skor }\end{array}$ & $\begin{array}{c}\text { Persentase } \\
(\%)\end{array}$ \\
\hline 1 & $\begin{array}{l}\text { Pemakaian warna } \\
\text { yang digunakan } \\
\text { menarik }\end{array}$ & 136 & 90,6 \\
\hline 2 & $\begin{array}{l}\text { Pemakaian warna } \\
\text { yang digunakan } \\
\text { tidak } \\
\text { mengacaukan } \\
\text { tampilan }\end{array}$ & 127 & 84,6 \\
\hline 3 & $\begin{array}{l}\text { Ukuran huruf } \\
\text { sudah sesuai dan } \\
\text { mudah dibaca }\end{array}$ & 125 & 83,3 \\
\hline 4 & $\begin{array}{l}\text { Warna huruf } \\
\text { sudah sesuai dan } \\
\text { mudah dibaca }\end{array}$ & 130 & 86,6 \\
\hline 5 & $\begin{array}{l}\text { Suara narator } \\
\text { terdengar jelas }\end{array}$ & 132 & 88 \\
\hline 6 & $\begin{array}{l}\text { Tombol/icon } \\
\text { yang ada terlihat } \\
\text { jelas }\end{array}$ & 132 & 88 \\
\hline 7 & $\begin{array}{l}\text { Animasi/simulasi } \\
\text { yang digunakan } \\
\text { menarik }\end{array}$ & 132 & 88 \\
\hline 8 & $\begin{array}{l}\text { Gambar pada } \\
\text { multimedia sesuai } \\
\text { dengan materi }\end{array}$ & 142 & 94,6 \\
\hline
\end{tabular}

\begin{tabular}{|c|c|c|c|}
\hline 9 & $\begin{array}{l}\text { Multimedia } \\
\text { memiliki } \\
\text { ketajaman } \\
\text { gambar yang } \\
\text { jelas }\end{array}$ & 122 & 81,3 \\
\hline 10 & $\begin{array}{l}\text { Multimedia dapat } \\
\text { dimulai dengan } \\
\text { mudah }\end{array}$ & 130 & 86,6 \\
\hline 11 & $\begin{array}{l}\text { Multimedia dapat } \\
\text { berjalan dengan } \\
\text { baik }\end{array}$ & 127 & 84,6 \\
\hline 12 & $\begin{array}{l}\text { Pengguna dapat } \\
\text { mengoperasikan } \\
\text { multimedia } \\
\text { secara mandiri }\end{array}$ & 121 & 80,6 \\
\hline 13 & $\begin{array}{l}\text { Materi yang } \\
\text { ditampilkan pada } \\
\text { multimedia jelas }\end{array}$ & 134 & 89,3 \\
\hline 14 & $\begin{array}{l}\text { Soal latihan } \\
\text { cocok dengan isi } \\
\text { materi }\end{array}$ & 132 & 88 \\
\hline 15 & $\begin{array}{l}\text { Pengguna tidak } \\
\text { merasa bosan } \\
\text { menggunakan } \\
\text { multimedia ini }\end{array}$ & 132 & 88 \\
\hline 16 & $\begin{array}{l}\text { Pengguna bebas } \\
\text { dari kesalahan } \\
\text { yang dapat } \\
\text { mengakibatkan } \\
\text { berhentinya } \\
\text { multimedia }\end{array}$ & 125 & 83,3 \\
\hline 17 & $\begin{array}{l}\text { Daya tarik } \\
\text { penyajian materi } \\
\text { sistem } \\
\text { pernapasan pada } \\
\text { manusia dalam } \\
\text { multimedia }\end{array}$ & 136 & 90,6 \\
\hline 18 & $\begin{array}{l}\text { Animasi pada } \\
\text { multimedia dapat } \\
\text { menjawab } \\
\text { ketidaktahuan } \\
\text { dalam } \\
\text { pembelajaran } \\
\text { sistem } \\
\text { pernapasan pada } \\
\text { manusia } \\
\end{array}$ & 139 & 92,6 \\
\hline 19 & $\begin{array}{l}\text { Daya tarik } \\
\text { penyajian materi } \\
\text { sistem } \\
\text { pernapasan pada } \\
\text { manusia }\end{array}$ & 123 & 82 \\
\hline \multicolumn{2}{|c|}{ Jumlah } & 2481 & 87,1 \\
\hline
\end{tabular}




\section{KESIMPULAN DAN SARAN}

\section{Kajian Produk yang Telah Direvisi}

Berdasarkan hasil penelitian dan pengembangan multimedia pembelajaran interaktif dengan menggunakan Software Adobe Flash CS6 Professional pada materi sistem pernapasan pada manusia, dapat dikaji sebagai berikut:

1. Pengembangan multimedia pembelajaran interaktif dengan menggunakan Software Adobe Flash CS6 Professional pada materi sistem pernapasan pada manusia dilakukan dalam beberapa tahapan yaitu: membuat konsep media, mempersiapkan bahan dari berbagai sumber, mempersiapkan silabus, menyiapkan materi, menetapkan animasi-animasi yang sesuai dengan materi, dan menetapkan narasi atau musik yang sesuai dengan materi yang akan digunakan untuk mengisi suara pada materi yang akan ditampilkan, kemudian menyatukan semua file kedalam Software Adobe Flash CS6 Professional, selanjutnya file di publish kedalam format swf dan dikemas dalam bentuk CD. Produk yang telah dikembangkan kemudian divalidasi oleh tim ahli materi dan ahli media. Validasi oleh ahli materi dilakukan sebanyak tiga kali revisi dengan hasil akhir setelah revisi berdasarkan saransaran dari ahli materi diperoleh skor $87,1 \%$, kategori sangat baik. Validasi oleh ahli media dilakukan empat kali revisi dengan hasil akhir setelah revisi diperoleh $80 \%$ kategori baik.

2. Hasil dari produk media yang telah direvisi oleh ahli materi dan ahli media kemudian diujicoba pada kelompok kecil dan kelompok besar dilaksanakan di SMPN 24 Kota Jambi dengan jumlah responden untuk ujicoba kelompok kecil 6 orang siswa dan ujicoba kelompok besar 30 orang siswa kelas VIII. Persentase tanggapan siswa SMPN 24
Kota Jambi terhadap media adalah $87,8 \%$ kategori sangat baik untuk ujicoba kelompok kecil dan 87,1\% kategori sangat baik untuk ujicoba kelompok besar. Dari hasil ujicoba tersebut dapat disimpulkan bahwa multimedia menarik dan mendapatkan respons yang sangat baik oleh siswa terhadap multimedia yang telah dibuat dan disajikan. Dengan demikian media pembelajaran berupa multimedia pembelajaran interaktif ini layak digunakan dalam proses pembelajaran biologi untuk siswa SMP kelas VIII.

3. Secara keseluruhan keunggulan dari multimedia interaktif yang dikembangkan yaitu memiliki desain yang berbeda dari multimedia yang sudah ada dan contoh yang digunakan menampilkan gambar yang jelas. Sedangkan kelemahan dari multimedia ini tidak bisa digunakan jika siswa tidak memiliki komputer atau leptop.

\section{Saran Pemanfaatan}

1. Multimedia pembelajaran interaktif pada materi sistem pernapasan pada manusia ini dapat membantu guru dalam proses pembelajaran dan dapat dijadikan sebagai sarana pembelajaran mandiri yang dapat digunakan siswa disekolah maupun diluar jam sekolah.

2. Multimedia pembelajaran interaktif pada materi sistem pernapasan pada manusia ini dapat dibuat dan dikembangkan lebih lanjut dalam bentuk serial lainnya atau menambahkan tampilan fitur-fitur yang lebih menarik dengan memperhatikan kelemahan dalam media yang dikembangkan.

3. Kepada peneliti selanjutnya disarankan untuk dapat menguji pengaruh penggunaan multimedia pembelajaran interaktif pada materi sistem pernapasan pada manusia terhadap hasil belajar siswa. 


\section{DAFTAR RUJUKAN}

Branch, R.M. 2009. Instructional Design the ADDIE Approach. London: Departement of Educational Psychology and Instructional Technology University of Georgia.

Djaali dan Muljono, P. 2008. Pengukuran Dalam Bidang Pendidikan. Jakarta: PT Grasindo.

Mulyatiningsih, A. 2012. Metode Penelitian Terapan Bidang Pendidikan. Bandung: Alfabeta.

Riduwan. 2010. Dasar-Dasar Statistika. Bandung: Alfabeta.

Rusman. 2013. Belajar dan Pembelajaran Berbasis Komputer Mengembangkan
Profesionalisme Guru Abad 12. Bandung: Alfabeta.

Sudaryono., Margono, G., dan Rahayu, W. 2013. Pengembangan Instrumen Penelitian Pendidikan. Yogyakarta: Graha Ilmu.

Setyosari, P. 2012. Metode Penelitian Pendidikan dan Pengembangan. Jakarta: Kencana.

Sugiyono. 2013. Metode Penelitian Pendidikan Pendekatan Kuantitatif, Kualitatif dan $R$ \& $D$. Bandung: Alfabeta.

Suhendi, E. 2009. Kreasi dengan Adobe Flash Professional. Bandung: Yrama Widya 
